\title{
From Romance to Vision: The Life of Breath in Medieval Literary Texts
}

\author{
Corinne Saunders
}

Therwith the sorwe so his herte shette That from his eyen fil there nought a tere, And every spirit his vigour in knette, So they astoned or oppressed were. The felyng of his sorwe, or of his fere, Or of aught elles, fled was out of towne; And down he fel al sodeynly a-swowne.

(Troilus and Criseyde, III, 1086-92)

And sumtyme sche myth not stondyn but fel downe amonge the pepil and cryid ful lowde, that many man on hir wonderyd and merveylyd what hir eyled, for the fervowr of the spiryt was so meche that the body fayld and myth not endur it.

(The Book of Margery Kempe, 6682-85)

Two images of extreme emotion: Troilus, overcome by the sight of his beloved lady Criseyde's tears, falls into a swoon; Margery Kempe, ravished

\footnotetext{
C. Saunders $(\bowtie)$

Department of English Studies, University of Durham, Durham, UK

(C) The Author(s) 2021

D. Fuller et al. (eds.), The Life of Breath in Literature, Culture

and Medicine, Palgrave Studies in Literature, Science and Medicine, https://doi.org/10.1007/978-3-030-74443-4_5
} 
by visions of Jesus and Mary, falls down to the ground, crying out loudly. Such descriptions seem part and parcel of the conventions and excesses of medieval writing: love-sickness, madness, longing sighs, and visionary swoons. Yet they speak to medieval understandings of breath and breathlessness, and the physiological models of emotion that underpin these, in ways that go far beyond convention. Consciousness and breath are intimately interwoven. Thinking about medieval breath requires frameworks that are not our own, yet have their own complex logic. Breath forms an essential element in medieval theories of the bodily spirits which govern life, feeling, and thought. In romance, the imaginative fiction of the Middle Ages, the play of emotions is dependent on the movements of the spirits, which engender the states of deep feeling, in particular, love and grief, that distinguish the genre. Such feeling is dramatically written on the body through the flight of breath in and out of the heart. In religious writing, these affective movements are the catalysts for moments of revelation and vision. Breath and breathlessness animate the individual relationship with the divine and the enactment of piety, often in extreme ways. Middle English romances, the works of Chaucer and Gower, the visionary poem Pearl, the Revelations of Divine Love of Julian of Norwich, and the Book of Margery Kempe all offer compelling examples of the centrality of breath to medieval conceptions of affect and the shaping of experience from romantic love to spiritual epiphany. The breathless body becomes the focus for explorations of the boundary between death and life, body and soul. The realisation of embodied being in medieval writing may be foreign in its workings, yet the meanings it conveys concerning the profound connections between breath, feeling, and consciousness remain powerfully and vividly relevant.

\section{Breath, Pneuma, and Embodied Being}

Breath and breathlessness become central to medieval understandings of feeling and emotion through the concept of the 'vital spirits' (pneuma/spiritus), to which breath is integral. These ideas take up Galenic models and Arabic extensions of them, to envisage the heart itself as 'breathing', as the vital spirits move in and out. ${ }^{1}$ Galen (129-ca. 216 $\mathrm{CE})$ followed the emphasis of Alexandrian medicine on the brain as the site of cognition and sensory perception. He also reworked Hippocratic and Aristotelian physiology to develop the theory of the bodily spirits. ${ }^{2}$ Aristotle had privileged the heart, conceiving of a mysterious, innate 
cardiac 'vapor' or breath, pneuma, as enabling perception, movement, and generation; Galen's model, by contrast, was rooted in his theories of pulsation. ${ }^{3} \mathrm{He}$ did, however, sustain Aristotle's notion of a tripartite soul, with vegetable, animal, and rational elements, following Platonic identifications of these with the liver, heart, and brain. ${ }^{4}$ All these required the 'instruments' ( organa) of pneuma and heat, which originated in the heart; the liver provided blood. Galen's pneuma was 'the vaporous substance ... formed ... in part by the inspired air and in part by the vaporization of the arterial blood', ${ }^{5}$ responsible 'for the transmission of sensation and other psychological and physiological faculties'. ${ }^{6}$ It 'exhale[d]' a purer, 'psychic pneuma' contained in the ventricles of the brain, which governed sensation and movement. ${ }^{7}$ Breathing, effected through the pores, supplied and replenished the air required to mix with blood in order to create pneuma and to cool the heart.

Later Galenism took up Galen's ideas, but also modified them. The concept of pneuma was elaborated, in particular, by the tenth-century Persian philosopher-physician, Avicenna (Ibn Sīnā). While Galen's main focus was the psychic pneuma (with some reference to that originating in the heart), Avicenna's Canon (1037), a comprehensive compendium rooted in Galenic medicine but also drawing extensively on Aristotle, set out a tripartite structure according to which the pneuma/breath was envisaged as modified into three kinds in the three principal organs. ${ }^{8}$ Pneuma (Latin, spiritus) formed 'the link between the body, soul and spirit'. ' Avicenna identified three 'faculties' or 'drives', corresponding with the three-part soul: natural or vegetative, located in the liver; vital, connected with the breath; and animal or sensitive, situated in the brain. A vital force, which Avicenna also terms 'breath' ('formed of the light and vapory part of the humours' (6.6.477) and produced in the heart), gave to all members of the body their 'virtues' or powers. Avicenna presented this vital force enabling the drives in mystical terms as 'a divine emanation' comparable to light (7.1.488). His model, then, was firmly cardiocentric: while he adopted Galen's view of the brain as essential to physiology, he followed Aristotle in placing the heart as origin of the life force, 'the one single breath which accounts for the origin of the others'. This was differentiated in the heart into the vital 'breath' or drive, and in turn enabled the natural and animal 'breaths' (7.1.489). From the vital breath arose the emotions; from the animal breath the senses and 'common sense', imagination, cognition, memory, and understanding. 
Early twelfth-century Latin translations of Arabic and Greek medical texts, many originating from the schools of Salerno and Toledo, disseminated Galenic and Arabic physiology to the Christian West, and provided the basis of Western medical theory. Particularly influential were the translations of Constantine of Africa, who practised at Salerno. Constantine's Pantegni theorica, which translated parts of the tenth-century Arabic medical encyclopaedia of 'Haly Abbas' ('Alī Ibn al-'Abbas al-Maǧūsī), in turn based on Galenic works, and his translation of the Isagoge Johannitii in Tegni Galeni, a treatise on the Galenic theory of humours and spirits by the ninth-century scholar and physician 'Johannitius' (Hunayn ibn Ishāq), became foundation texts for the Articella or Ars medicine, the collection of six medical works that entered the university curriculum in the thirteenth century. Translation and circulation of other medical texts was rapid and extensive. A translation of Avicenna's Canon, attributed, along with a range of Galenic treatises, to Gerard of Cremona (d. 1187, translator of many scientific works), probably made in the thirteenth century by Gerard de Sabbioneta (also often known as/confused with Gerard of Cremona), was taken up in Toledo and introduced in the curricula of Montpellier, Paris, and Bologna at the end of the thirteenth century. ${ }^{10}$ Avicenna's influence is evident through references to his work in the later thirteenth century, including in the scholastic writings of Roger Bacon, Albertus Magnus, and Bartholomaeus Anglicus. Vincent of Beauvais' widely circulated Speculum naturale (ca. 1235-64) draws on the Canon, and copies were owned in England by the late thirteenth century, including by the Benedictine foundations Christchurch Priory and St Augustine's Abbey, Canterbury. Ideas concerning the pneuma/spiritus were of interest to theologians on account of their bearing on debates concerning the relationship between material and spiritual and the unity of the soul. ${ }^{11}$ The pneuma was most often seen as the 'instrument of the soul' but sometimes, in its 'animal' form in the brain, as the corporeal soul itself. ${ }^{12}$ Breath, then, played a key part in physical, intellective, and spiritual being.

By the later fourteenth century, this physiological model was widely circulated, rendered accessible in lay circles through vernacular works such as John Trevisa's translation of Bartholomaeus Anglicus' encyclopaedic De proprietatibus rerum. Trevisa's description closely parallels Avicenna's and draws on Constantine's Pantegni: 
Out of pe herte comep lif to al pe limes. [...] Pis vertu of lif openip pe herte by worchinge of pe longen and drawep in aier to the hert and sendip forp from pe herte to opir limes by smale weyes. And by help of pe vertu pat closith and riuep and openith pe herte pis vertu worchip and makep brepinge in a beest. And by brepinge pe brest meuep continualliche, but sinewis and brawnes bep first imeued. Pis blast, brep, and onde [wind] is nedeful to slake pe kindeliche hete, and to foode of pe spirit of lif, and also to pe gendringe of pe spirit pat hatte animalis pat zeuep felinge and meuynge. 13

Breath cools the heart where the 'virtue' or power of life begins. Through breath are generated the vital spirits-here seemingly synonymous with the 'vertue vitall' - which in turn create the animal spirits. The lungs take in air and convey it to the heart, cooling it and providing the air that will be transformed, mixed with blood, to the vital spirits:

Pe kepinge of pe kinde hete is a temperat indrawinge of coold aier and pe kepinge of pe spirit pat hatte spiritus vitalis 'of lif'. Of pe temperament of pis spirit is pe spirit gendrid pat hatte animalis pat zeuep felinge. Perefore noping is more nedeful to kepe and to saue pe lif pan brep, wel disposid and ordeyned in alle pointis. Al pis seip Constantinus in Pantegni. (III.15, 105 )

As Carole Rawcliffe shows in this volume, these ideas, originating from Constantine of Africa's translations and Avicenna's Canon, also found their way into the regimens of health that circulated widely across Western Europe. ${ }^{14}$

The framework of the bodily spirits was crucial to medieval understandings of the emotions and psychology. Thirteenth-century natural philosophy drew on Avicenna, in particular his De Anima (translated into Latin in the twelfth century), to elaborate the processes of thought enabled by the animal spirits, seen as occurring in the ventricles of the brain. Breath was intimately connected with the emotions, which were believed to occur through the movements of the vital spirits and natural heat, produced in the heart and travelling through the arteries. In joy or anger, the vital spirits and accompanying heat rushed out from the heart, marked on the body by physical responses such as blushing. In grief, distress, or fear, the vital spirits and heat withdrew into the heart, reflected in pallor or swooning. Withdrawal of the spirits equated to withdrawal of breath: at its most extreme, this could cause unconsciousness 
or even death. Sighs and tears were believed to carry the overburdening spirits out of the heart, purging and cooling it, though sighs might prove dangerous in excess, causing the heart to dry out and wither. The concept of the porous, breathing heart pervaded literary and theological works. As Webb emphasises, the senses were 'imagined to bring something from the outside world into the heart', stimulating the vital spirits:

The spiriti generated in the medieval heart created different possibilities for the experience of the world. They extended far beyond the boundaries of a single body, reaching into other bodies and thus forming the potential for a certain porosity of selfhood that corresponded to the porosity of the heart.... The medieval heart ... was meant to be promiscuous; the world rushed into it with every breath. ${ }^{15}$

Love, grief, melancholy, then, were profoundly bodily, 'spiritual' in a material, bodily sense, as well as felt in the soul, treated by physicians as well as philosophers and imaginative writers.

The classical notion of pneuma related in complex ways to Christian conceptions of the Holy Spirit. As Thomas Hunt demonstrates in this volume, while immateriality was emphasised, physical notions of air, voice, and breath continued to resonate with conceptions of the Spirit. In the later medieval thought-world, the theory of the bodily spirits encouraged such blurring. The influential writings of St Paul depict the Spirit of divinity and life as external to the individual, moving within the cosmos, yet the Spirit is also inspiring and inspired, moving souls, breathing new life into them. St Augustine, whose works laid the foundation for later medieval theology, employs the concept of spiritus (pneuma) to explore both the immaterial quality of the divine and the life force. ${ }^{16}$ The Holy Spirit might be understood as the divine spark, igniting the vital fire within the heart. The dual sense of spiritus/pneuma, as breath of God and vital spirits, gives the breath a special status in conceptions of the animating force, its ramifications both physical and spiritual. The heart of Christ and the heart of the lover were in many ways analogous, infused by the Spirit and profoundly wounded by the spirits, breathing out tears and sighs. 


\section{Fainting Hearts}

Medieval romances are imbued with-and take for granted - the extreme affects of love. Such affects are fundamental to romance sensibilities, but they are also deeply embedded in medieval physiological and psychological models. Romance reworkings of the classical topos of love-sickness are invested with realism in ways not likely to be apparent to modern readers. They assume the movement of the spirits and their affective play on the body, and can also include sophisticated medical detail. Swoons, shrieks, and sighs signal emotional extremes; they also play essential narrative roles, their affects heightened by their physiological grounding. Romance treatments of love can be highly sophisticated, drawing on detailed medical knowledge, as in Chaucer's writings, but the broad outlines of physiological and psychological models to which the affective play of breath is integral are also evident in much less conspicuously learned works, demonstrating the pervasive power of such ideas from the thirteenth to the fifteenth centuries.

The thirteenth-century French dream-vision Le Roman de la Rose (begun by Guillaume de Lorris and completed by Jean de Meun), parts of which were translated into English by Chaucer in the late fourteenth century, offers the archetypal model of medieval love-sickness. ${ }^{17}$ The Lover is wounded by the arrow of the God of Love: 'Than I anoon gan chaungen hewe / For grevaunce of my wounde newe, / That I agayn fell in swonyng / And sighede sore in compleynyng' (1865-68). ${ }^{18}$ The pallor of his countenance and his ensuing faint bespeak the withdrawal of the vital spirits into the heart; his sighs send forth the overburdening spirits, while the poem too is a voicing of his 'compleyning'. In Chaucer's Knight's Tale, the walls of the temple of Venus are painted with images of love-sickness: 'The broken slepes, and the sikes colde, / The sacred teeris, and the waymentynge, / The firy strokes of the desirynge' (192022 ); in The Parliament of Fowls the lover's sighs are 'hoote as fyr', 'sikes engendered with desyr' $(246,248)$. The rushing out of the vital spirits in passionate desire creates hot sighs, while cold sighs reflect the absence of warmth effected by grief, when the spirits have withdrawn from the rest of the body. The Ovidian paradoxes of fire and ice, the burning and longing sighs of love, are famously taken up by Petrarch, recurring across medieval and early modern love poetry, and repeatedly used in Renaissance madrigals, where the word 'Ohime' (Alas!) with its two falling tones musically represents the sighs of the lover. 
Middle English popular romance demonstrates just how widespread the physiological model of the vital spirits and the connection of breath with emotion are. The early romance Floris and Blanchefleur (Middle English ca. 1250, based on an earlier French romance), popular across Europe, exemplifies this. The stylised narrative relies on patterning, convention, and repetition, yet these are integrated with the physiological realisation of emotions at work. When the protagonist Floris, a Spanish prince whose parents are unwilling to let him marry a Christian, is told that his beloved Blanchefleur is dead, he swoons in response, meeting death with seeming death. ${ }^{19}$ In turn, his swoon evokes the affective responses of the queen and king, whose heart is 'al in care' (253); on seeing Blanchefleur's grave, his response is heightened: 'Thre sithes Florys sownydde nouth; / Ne speke he myght not with mouth' (267-68); when he 'awoke' (269) from his swoon, a verb pointing up the death-like effect of the spirits withdrawing, his grief leads him to attempt suicide. It is the extremity of Floris' grief, lived out in his swoon, that causes his mother to fear for his life and his parents to reveal that Blanchefleur is living. On hearing that she has been taken to Babylon, Floris' spirits rise: he 'in his hert bygan to lyght' (417), and he plans to follow her there. The movements of breath, then, are carefully manipulated in relation to the plot, with swooning placed both to signal extreme distress and to effect a turning point.

A second early Middle English romance, King Horn (ca. 1225), deploys the play of the vital spirits to characterise its strikingly active female protagonist, Rymenhild. Her desire is manifest in near-madness that disorders the animal spirits generated by the vital spirits: she 'lovede so Horn child / That negh heo gan wexe wild [mad]'; 'in heorte heo hadde wo'. ${ }^{20}$ Her rejection by Horn is dramatically reflected in the withdrawal of the vital spirits: 'Tho gan Rymenhild mislyke, / And sore gan to sike. / Armes heo gan bughe [bend]; / Adun he feol in swoghe' (42528). Again the swoon has a pivotal narrative function, effecting in turn a change in Horn's spirits: 'Horn in herte was ful wo' (429). Rymenhild's shock at her dream warning of his departure again draws the animal spirits from the brain, affecting her inner 'wits' or faculties: she sits numbed, 'also he were of witte [out of her wits]' (652), an image repeated at the thought of her enforced marriage (1086). The deathly movement of the spirits into the heart is made explicit when she believes Horn to be dead: her heart 'bigan to chelde [grow cold]' (1150), echoing her swoon. The movement of the vital spirits, the play of breath governed by 
them, and their power over the wits animate the depiction of Rymenhild's remarkable agency.

Chaucer, a century later, portrays such affective responses, in which breath moves in and out of the heart, with remarkable medical detail. His engagement with physiology and conversance with works such as Trevisa's is evident across his oeuvre, investing his depictions of emotion with a realism rooted in knowledge of the complex workings of mind, body, and affect. Chaucer's early dream vision The Book of the Duchess (136972 ) probes the physiology of loss and grief. The narrator's unexplained melancholy, which we assume to be caused by love, has 'sleyn [his] spirit of quyknesse' (26) — afflicted the vital spirits—and deprived him of sleep. The classical story he reads, of Ceyx and Alcyone, echoes his own fleeting spirits in its account of Alcyone's grief-stricken swoon at hearing that her husband is drowned. She is 'cold as ston' (123), waking only to die within three days: the most extreme manifestation of the flight of the vital spirits into the heart. In the narrator's dream of the grieving Man in Black such a withdrawal of the spirits is elaborated in precise medical detail:

His sorwful hert gan faste faynte

And his spirites wexen dede;

The blood was fled for pure drede

Doun to hys herte, to make hym warm-

For wel hyt feled the herte had harm.... (488-92)

No physician, 'noght Ypocras ne Galyen [Hippocrates or Galen]' (572), can treat his heart. The terms, however, are clearly reminiscent of Galenic physiology. Withdrawal of vital spirits and breath effects faintness; the flight of blood into the heart, the 'membre principal' (495) of the body, causes 'al / Hys hewe chaunge and wexe grene / And pale' (496-98). Loss of the beloved engenders loss of vital spirits and renders body and mind 'ded as stoon' (1300).

Chaucer's epic romance Troilus and Criseyde (ca. 1382-85) offers still more extended physiological detail. The narrative of Troilus' double sorrows is the narrative of his heart wounded in love and loss, and of the extreme movements of the vital spirits written on his body. Chaucer enhances and medicalises his source, Boccaccio's Il Filostrato (ca. 1335/40). He draws on both neo-Platonic convention and the kind of Aristotelian notions taken up by Avicenna to describe how, on seeing Criseyde, Troilus' heart is affected through the eyes: it is caused to 'sprede 
and rise' as if on fire, wounding and quickening his 'affeccioun [desire]' $(\mathrm{I}, 278,296)$ as the vital spirits rush outwards. But the enduring effect is that of withdrawal of the over-burdened spirits: Troilus feels that 'with hire look [will die], the spirit in his herte' (I, 307). Again and again, the illness of the heart consumes the body. When, on seeing Criseyde weep, Troilus feels 'the crampe of deth to streyne [constrain] hym by the herte' (III, 1071), and faints, Chaucer offers careful physiological detail:

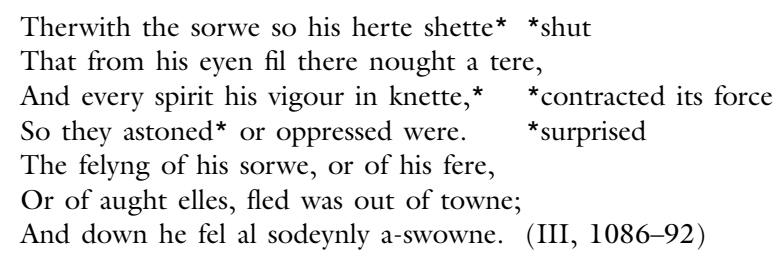

The sudden, complete withdrawal of the vital spirits and of the breath that they govern causes unconsciousness. Here, the connection between pulsation and the heart is comically reiterated as Pandarus and Criseyde chafe Troilus' pulse and palms until breath returns. But ultimately, Troilus' entire physical being is unmade: so extreme are the pallor, emaciation, and weakness caused by the affects of love that he is unrecognisable, walking with a crutch $(\mathrm{V}, 1219-25)$. Chaucer envisages the physical pressure of the withdrawing spirits: Troilus complains of grievous pain around his heart. Yet, ironically, Troilus' death is caused not by the final loss of breath in love but when he is slain in battle by Achilles. Now freed from the torments of the bodily spirits, his 'lighte goost' (V, 1808) looks down and laughs at the sufferings of those on earth.

Chaucer's engagement with that moment at which the vital spirits withdraw is also evident in his graphic account of the lover Arcite's death at the end of the Knight's Tale, written at approximately the same time, and drawing on another work of Boccaccio, Il Teseida. Here, Chaucer explores the possibility of physical rather than emotional pressure on the vital spirits. An injury to Arcite's chest when he is thrown from his horse prevents the clotted blood from being expelled: with 'the pipes [tubes] of his longes' swollen and the muscles in his chest 'shent [destroyed] with venym and corrupcioun [decayed matter]' (2752-54), the spirits fail in their 'vertue' of expelling the poison. The 'vital strengthe' (2802) is cut off, unable to circulate, and the 'coold of deeth' comes upon his body 
(2800). Only his 'intellect' (2803), his consciousness, remains, manifest in his eyes and plea of 'Mercy' to Emilye (2808). But this too fails 'whan the herte felte deeth' (2805). The vital spirits are unable to animate the body: 'Dusked his eyen two, and failed breeth' (2806). Separated from the body, Arcite's 'spirit', now synonymous with his soul or, in this tale with its classical framework, psyche, changes 'hous' to another, celestial dimension (2809). The episode disentangles the complex connections between heart, spirits, intellect, breath, and soul of the lover, and probes the workings of the breathing body and mind.

\section{AwAKening Life}

The movement between death and life, the visibility of the vital spirits and the possibility that breath may be latent yet present, all these coalesce in the figure of the seemingly dead lady. The motif echoes down the centuries, spanning both fairy tale-the Sleeping Beauty stories-and tragedy-Romeo and Juliet. It finds its most influential pre-modern treatment in the tale of Apollonius of Tyre, extant in a Latin version but probably based on a Greek prose fiction, retold in several medieval versions, most extensively by Chaucer's contemporary John Gower in Book VIII of his Confessio Amantis, and by Shakespeare in Pericles, where 'ancient Gower' is his Chorus. Marie de France's lai of Eliduc offers a partial twelfth-century Anglo-Norman analogue. Marie is specific about the absence of breath when the lady Guilliadun swoons, seemingly dead, on discovering that her lover Eliduc is already married:

Desur sun vis cheï paumee,

Tute pale, desculuree.

En la paumeisun demurra, Que el ne revient ne suspira.

Cil ki ensemble od lui l'en porte

Quidot pur veir ke ele fust morte.

(She fell on her face in a faint, all pale, colorless.

She remained in her faint, she did not recover or sigh.

He who is taking her with him truly believed that she was dead. $)^{21}$ 
Later, Marie emphasises Eliduc's wonder, on visiting her corpse, at the fact that she has lost little of her colour. As with Juliet, death's pale flag is not yet advanced in her countenance, the clue that she only seems dead. When Eliduc's wife Guildelüec discovers her, Guilliadun's gem-like beauty is described in terms of marvel. Yet though her recovery too is wondrous, it is also medicalised, effected through the application of a herb that heals a weasel killed by the wife's servant. Marie offers realistic detail about how the herb is placed within the maiden's mouth, so that 'Un petitet i demurra, / Cele revint e suspira' ('Just a little while she waited: / the girl recovered, and sighed', 1063-64). Guildelüec emphasises Eliduc's confusion between swoon and death: the original meaning of Old French 'pasme', 'cramp', a sudden taking or spasm, suggests the suddenness of swooning, its death-like quality. This is a near-death state which medical knowledge can resolve, not a sleep to be awakened by love. But the swoon also enables the probing of Eliduc's love through his grief, and the resolution of the dilemma through Guildelüec's wonder and pity, leading her to give up her husband.

Similar emphases are found in the Apollonius story, which is reworked by Gower to probe the boundary between marvel and medicine, fantasy and reality. The classical text offers specific detail about the swoon, which occurs in childbirth: 'While they were delayed at sea ... the girl gave birth in the ninth month. But the placenta failed to be discharged, her blood clotted, her breathing became constricted, and she suddenly died. ${ }^{22}$ The focus of the doctor's pupil who revives her is on breathing:

The young man took a jar of unguent, went to the girl's bier, pulled aside the clothing from the upper part of her body, poured out the unguent, ran his suspicious hands over all her limbs, and detected quiescent warmth in her chest cavity. The young man was astounded to realize that the girl was only apparently dead. He touched her veins to check for signs of movement and closely examined her nostrils for signs of breathing; he put his lips to her lips, and, detecting signs of life in the form of slight breathing that, as it were, was struggling against false death, he said, 'Apply heat at four points'. When he had had this done, he began to massage her lightly and the blood that had coagulated began to flow because of the anointing. ... Her blood, which had congealed because of severe cold, began to flow once heat was applied, and her previously obstructed breathing began to infiltrate to her innermost organs. (753-54) 
The liberation of the vital force effected by warming the blood unlocks the breath.

Gower's narrative is rooted in intimate familiarity with medieval medical theory, taking up the idea of the vital spirits to emphasise the physiological underpinnings of what might seem magical. His account of the swoon, the absence of breath that seems to take away life itself, is briefer but acute: Apollonius' queen is 'ded in every mannes syhte', her loss inspiring him to swoon in turn. ${ }^{23}$ Recovery is realised with precise detail, as the physician Cerymon searches and finds 'a signe of lif' in the body (VIII, 1189). His actions follow established medical procedure for reviving the vital spirits, drawing them out of the heart: he lays the queen on a soft couch, lights fires, warms her breast, anoints her joints with 'certein oile and balsme', and 'putte a liquour in hire mouth, / Which is to fewe clerkes couth'-a learned parallel to the life-giving herb in Eliduc (VIII, 1198-1200). While the revival of the seemingly dead lady speaks to the wish-fulfilment quality of romance, it is carefully depicted so as to appear not as magic but skilled medicine, which uses specialised, learned arts of healing, heat, aromatic scents, and 'liquour' (all cures recommended to physicians), to reawaken the vital spirits in the heart so that it begins to 'flacke and bete', and revive the 'colde brest', returning breath to the body (VIII, 1195-96). Gower enhances affect for reader and spectator by rooting marvel within the realistic possibilities of medicine, using a contemporary physiological framework to make real the possibility of waking the dead.

Engagement with the play of breath and the precise physiology of the vital spirits that govern the emotions, then, allows romance writers to dramatise the physicality of intense experience and the embodied quality of emotion; to illuminate the intimate connections between mind, body, and affect; to probe the nature of spirits, intellect, and soul; and to explore the mysterious boundary between life and death. Moments of extreme emotion, particularly enacted through the swoon, the flight of breath into the heart, are crucial turning points and foci for the revelation of the psyche. Romance structures and their conventions have their own spiritual force: they work to evoke and animate the texture of human experience, of breathing, being, and dying in the world. 


\section{SWOONING INTO Vision}

The physiology of the bodily spirits and breath plays a central part in romance; it also powerfully infuses religious writing, in particular, visionary writing with its emphasis on individual spiritual experience. ${ }^{24}$ The long history of the concept of pneuma, its complex intersections with life force, spirit, and soul, and the essential connection between vital spirits and breath all played a crucial part in the bodiliness of medieval devotion. Inspiration by the spirit was not cerebral but profoundly physical: a literal inspiring. The start of Richard Rolle's Incendium Amoris (The Fire of Love, ca. 1343) memorably depicts the blurring between physical and spiritual: Rolle feels the heat of the flame of divine love, touching his breast to see whether his heart is literally on fire: 'it set my soul aglow as if a real fire were burning there'. ${ }^{25}$ Such representations are intimately connected with the notion of the breathing heart, its heat infused and increased by the vital spirits. Vital spirits, soul, and Holy Spirit seem to intersect. As in romantic love, the individual responds to and with overpowering love that can manifest itself in the flight of the spirits into the heart, causing not just sighs that relieve its fire but also swoons, while the rushing out of the spirits is marked by tears and sobs, the disruption of breath. There was no clear boundary between theology and natural philosophy, and learned clerics are likely to have been broadly familiar with physiological concepts such as that of the vital spirits, and to have recognised the coincidence of this model with ideas of the Spirit as inspiring, moving force. Monastic libraries owned copies of works such as Avicenna's Canon and Bartholomaeus' De proprietatibus rerum, suggesting the interest of religious as well as lay readers in both physiology and psychology. Religious writers take up conventional images and metaphors, reworking them with new force in the light of new understandings of breath and the spirits.

The late fourteenth-century Middle English alliterative poem Pearl merges the conventions of romantic and divine love in its dream-vision. Here again the swoon, withdrawing breath, is the catalyst, effecting a transformation in the Dreamer-narrator. Grief at the loss of his pearl, probably his infant daughter, leads him to fall down onto the grass 'vpon a slepyng-slazhte': the term 'slazte' has the sense both of a sudden blow and of death, implying a sudden, death-like sleep. ${ }^{26}$ From this place his 'spyryt per sprang in space', liberated from his body, into 'sweuen' or vision (61-62). This swoon of grief becomes a form of dying to live, looking towards the redemption offered by actual death. It is not waking 
but the swooning sleep itself that is medicinal, opening onto a visionary, celestial world of blue and silver trees where precious pearls crunch under the feet and the Dreamer sees his daughter transformed into a beautiful bride of Christ. The change in breath-state marks the crossing of an ontological boundary, but the Dreamer cannot fully enter into the celestial world: his attempt leads him to wake at the end of the poem 'sykyng' (1170) and swooning in grief (1180) at the loss of his visionary state. Waking breath remains synonymous with loss, even while it is infused with the possibility of embodied vision.

In Julian of Norwich's Revelations of Divine Love too, the swoon becomes a kind of dying to live. But this instance is partially voluntary, leading beyond loss. The Revelations recount the visions experienced by Julian in 1373 as she lay apparently dying at the age of thirty. The illness occurs in answer to her prayer to experience three miracles, one of which is to 'have all manier peynes bodily and ghostly that I should have if I should dye, with all the dreds and tempests of the fends, and all maner of other paynes, except the outpassing of the soule'. ${ }^{27}$ All three of her wishes are fulfilled at once: the loss of all but spiritual comfort, visual experience of Christ's Passion, and the three wounds of contrition, compassion, and 'willfull longyng to God' (ch. 2, 30). The description of Julian's illness accords with medieval physiological models. It is characterised by withdrawal of the breath, signifying the withdrawal of the vital spirits, and hence, by the failure of sight and feeling occasioned by the effect of that withdrawal on the animal spirits:

After this the over party of my body began to dyen so ferforth that onethys I had ony feleing. My most payne was shortnes of onde [breath] and failyng of life. And than I went sothly to have passid. And, in this, sodenly all my peyne was taken fro me and I was as hole, and namely in the over party of my body, as ever I was aforn. (ch. 3, 32)

In this near-death, trance-like state, Julian experiences fifteen of her sixteen visions. Then her sickness returns, in her head 'with a sound and a dynne', and in her body, 'sodenly all my body was fulfillid with sekenes like as it was aforn, and I was as baren and as drye as I never had comfort but litil' (ch. 66, 136). Dismissing the visions as 'raving' and then repenting of her disbelief, she falls asleep, to feel the devil taking her by the throat. Sleep and waking overlap as 'anon a lytel smoke came in the dore with a grete hete and a foule stinke' (ch. 66, 137)-the 
breath of the devil opposing the power of the Spirit and her own vital spirits; later, the fiend returns 'with his hete and with his stinke' (ch. 69, 142). Images of air and wind recur. In the eighth revelation, inspired by Christ's words, 'I thirst', Julian sees his flesh shrivelling in death, like cloth hung out to dry, pained 'with blowing of the wynde from withowten that dryed him more, and peynd with cold, than myn herte can thynkyn' (ch. 17, 57-58). Spiritual dryness, the cold breath of despair, and the smoke of hell are countered by the breath of the Holy Spirit, which brings life and rest, 'the Holy Gost graciously inspirith [breathes] into us gifts ledand to endless life'. The soul will ultimately perceive God with all the senses: 'hym verily seand and fulsomly feland, hym gostly heryng, and hym delectably smellyng, and hym swetely swelowyng' (ch. 43, 98). He is breathed in as well as breathing into, inspired and inspiring. This is the all-consuming, true vision inspired by the Spirit, seeing face to face rather than 'through a glass darkly'. Julian's experience is fully embodied as her own breath and that of the spirit world around her intermingle.

Nothing is known about Julian's life beyond the fact of her anchoritic existence, but the theological sophistication of her interpretations suggests deep reading and knowledge, perhaps the result of spiritual instruction by her confessors. While Pearl ends with the sighs and swoons of grief and longing for lost vision, the Long Version of the Revelations combines with visionary moments the meanings contemplated for twenty years, creating a breath-world the textures of which are both inspired and deeply thought-through.

It is in The Book of Margery Kempe that we find the most extended treatment of the play of breath in affective piety. Though her name is frequently linked with that of Julian of Norwich, the life of Kempe (born ca. 1373) was far from anchoritic: married, she bore fourteen children, ran a brewing business, and travelled on pilgrimage as far as Rome and Jerusalem. She too, however, was a visionary who adopted a severely ascetic life-and her references to many devotional texts make clear the shaping of her imagination by the kind of meditative tradition that Julian would have practised, of projecting the self into, and empathising with, scenes of Christ's life. Unlike Julian's Revelations, Kempe's Book (143638) does not offer extended theological interpretations. Its status is complex: it is mediated by two amanuenses, its illegible first version interpreted, rewritten, and extended by a second scribe some twenty years after the earliest experiences it recounts. The process of writing and the 
accounts in the Book of Kempe's programme of reading with her priestconfessor, however, suggest an intellectual context in which physiological and theological ideas concerning breath, the spirits, and the inspiration of the Spirit would have been familiar. At the same time, the breath-world of the Book is uniquely and immediately Kempe's own.

Its primary focus is 'inspiration', being literally breathed into by the Holy Spirit. The images of tears, hearts, and flames signifying such inspiration that dominate the Book are familiar, extending back at least to St Bernard of Clairvaux and forward to the hearts and flames drawn in the margin by sixteenth-century readers. But they also have a powerful material meaning that keys into medieval understandings of the connections between mind and body, the movements of the vital spirits and the feelings they stimulate, and especially, the workings of the animating Spirit. While Kempe's down-to-earth, sometimes simplistic account of spiritual revelation and grace has been dismissed for its conventionality, Kempe's embodied experience may also be seen as shaped by contemporary physiological concepts. The emphases of the Book on fire in the heart and compulsive weeping are not simply performances of piety, but correspond with models of feeling that are bound up with the breath. Profound affect exacerbates the heart's heat, so that the vital spirits are emitted in sighs, tears, and cries, while extreme grief causes them to rush violently back in and leads to swoons.

From the start, Kempe's inward life is intimately associated with the body. The Book recounts Kempe's 'mevynggys and hyr steringgys' as she is 'enspyred of the Holy Gost', and the stirrings of others to believe in her: the breath of the Spirit works on her own breathing body. ${ }^{28}$ The feeling and sound of divine breath is a repeated motif. Kempe's conversion is brought about by a melody 'so swet and delectable, hir thowt, as sche had ben in paradyse' (325-26), which inspires 'greet sobbyngys and syhyngys aftyr the blysse of heven' (333-34); she is 'drawt [drawn]' (335) to God. As well as further 'gret sowndys and gret melodiis' (6224) that signal heavenly merriment, she hears the noise of the bellows blowing, explicitly identified as the 'the sownd of the Holy Gost' (2968). The sound becomes that of a dove, the traditional symbol of the Holy Spirit, and then a robin, all inspiring 'gret grace' (2972). Kempe both experiences divine pneuma through sight, sound, and feeling and is consumed by that breath, which enters into her heart. The traditional association of the Holy Spirit with fire as well as breath is pointed up by the narrative's repeated descriptions of the fire or flame of love: 'sche had many holy 
teerys and wepingys, and oftyntymys ther cam a flawme of fyer abowte hir brest ful hoot and delectabyl' (7369-71). In Kempe's visionary experience, the flame is not simply a metaphor for ardent love, but a literal representation of the inspiration of the heart by the Spirit, profoundly and often painfully physical. Her heart is so far 'consumyd wyth ardowr of lofe' (929-30) that, like Troilus, she swoons: 'unmythy to kepyn hirselfe in stabilnes for the unqwenchabyl fyer of lofe whech brent ful sor in hir sowle' (3242-44). The Book also, however, suggests conflicting models: while the Carmelite friar Alan of Lynn and other clerics attempt to persuade Kempe's enemy, the learned Franciscan William Melton, that her experience is genuinely spiritual, Melton suspects she suffers from a disease of the heart ('a cardiakyl,' 5063).

Kempe's cryings, which commence with her first vision of heaven and continue over her entire life, are closely connected to her experience of the fire of love. While the cryings are often singled out in critical discussions of Kempe, they may better be understood as one aspect of her embodied devotion, making manifest the workings of the Spirit that connect heart and mind through the breath-play of the vital spirits. Tears are a long-standing religious topos and partial analogies may be found in the weeping of Christ, the Virgin, and Mary Magdalene, while reading of the tears of Mary of Oignies inspires belief in the priest who condemns Kempe, but the Book also emphasises the discomfort and wonder of her cryings. Her tears respond to the trauma of the Passion, marking her sharing of Christ's pain, but her 'synguler and ... specyal yyft' (3268) is also extreme and compulsive, transformed when she travels to Jerusalem into a 'krying and roryng' (2216), 'plentyvows terys and boystows sobbyngys, wyth lowde cryingys and schille shrykyngys' (3534-36). The repeated connection with physical 'fallyng' (2190) suggests the most extreme effect of the vital spirits drawn into the heart through profound emotion ('the fervowr of the spiryt was so meche that the body fayld', 6684-85), and hence, the violent disruption of breath. The connection with breath is made differently explicit when Kempe turns blue or the colour of lead from the intensity of her cryings (2256), a symptom often connected with epilepsy, but one that readily fits the model of the vital spirits rushing into and out of the heart in a combination of ecstasy and grief. Overcome by the passions, the heart draws in more breath through gasps and sobs, while the withdrawing vital spirits deprive the rest of the body of its animating force. Crying and falling, 'these bodily mevyngys' (2278), the effects of the rush of spirits and breath, are thus closely linked 
to the flame of pneuma/spiritus in the heart: theological and physiological models intersect in the meeting of air and fire.

While Kempe herself may not have been conversant with the detail of medical or philosophical theory, at least some members of the East Anglian clerical circle with which she engaged will have been able to offer generalised models for the workings of emotional and spiritual experience. As medieval romances show, these ideas permeated the medieval thoughtworld down to its popular roots. They were available in the texts and lives that influenced Kempe and shaped her spiritual experience, animating her Book. To place Kempe's behaviours simply as conventional or performative-or to define them in pathological terms according to modern medical disorders-ignores the physicality of contemporary understandings of divine inspiration and of emotion. ${ }^{29}$ Breathing connects mind and body, sends the vital spirit from the heart to the brain, kindles the fire of love, and in extreme emotion also stimulates the disturbance of the vital spirits that causes severe crying and falling, a rushing out of the fire and a sudden withdrawal of the spirits into the heart. Kempe's Book presents an embodied spirituality that is strange, uncomfortable, extreme yet also explicable-a breathing, inspiring spirituality. Like the Dreamer in Pearl, she is consumed by the depth of her feeling. As with Julian, her identification with the Passion leads to revelatory, all-encompassing experience in which her entire body is caught up by the Spirit. For the visionary, human breath mingles with divine, vital spirits with the Spirit, to effect a breathing being not so unlike that of the fainting lover of romance, consumed by passion. These swoons, however, also evoked by deep desire, are not to be woken from but ardently sought after, for in them, the fire and air of the heart, spirits and Spirit meet.

Medieval breath, then, was profoundly 'spiritual'-integral to emotional experience, both romantic and divine, and to the essential force of life. The thought-world of medieval literature is rich and strange. Yet in the world of the twenty-first century, where breath has become more and more prominent, opening onto the most fundamental issues of health, belief and freedom, that strangeness of breath's spirituality resonates with uncanny relevance.

\section{Notes}

1. Heather Webb, The Medieval Heart (New Haven, CT: Yale University Press, 2010), see especially ch. 2, 'The Porous Heart', 50-95. 
2. Armelle Debru, 'Physiology', The Cambridge Companion to Galen, ed. by R. J. Hankinson (Cambridge: Cambridge University Press, 2008), 263-82: 275. On the progression of Greek thought on pneuma and Galen's response to it, see further Geoffrey Lloyd, 'Pneuma between Body and Soul', in Wind, Life, Health: Anthropological and Historical Perspectives, ed. by Elisabeth Hsu and Chris Low, The Journal of the Royal Anthropological Institute 13, issue s1 (2007): S135-S146.

3. Mario Vegetti, 'Between Knowledge and Practice: Hellenistic Medicine', in Western Medical Thought from Antiquity to the Middle Ages, ed. by Mirko D. Grmek, co-ord. by Bernardino Fantini, trans. by Antony Shugaar (Cambridge, MA: Harvard University Press, 1998), 72-103: 7778; see further Gad Freudenthal, Aristotle's Theory of Material Substance: Heat and Pneuma, Form and Soul (Oxford: Clarendon Press, 1995).

4. Gerald J. Grudzen, Medical Theory About the Body and the Soul in the Middle Ages: The First Western Medical Curriculum at Monte Cassino (Lewiston: Edwin Mellen Press, 2007), 57; Debru, 'Physiology', 268.

5. See Galen, On the Use of Breathing (De Usu Respirationis) in Galen: On Respiration and the Arteries, ed. by David J. Furley, and James S. Wilkie (Princeton: Princeton University Press, 2014), ch. 5, K502, 120-2; Debru, 'Physiology', 272. See also A. A. Long's essay in this volume.

6. Debru, 'Physiology', 272.

7. Debru, 'Physiology', 275.

8. Vivian Nutton, 'The Fortunes of Galen', The Cambridge Companion to Galen, 355-90: 364; Nancy G. Siraisi, Avicenna in Renaissance Italy: The Canon and Medical Teaching in Italian Universities after 1500 (Princeton: Princeton University Press, 2014), 29. For an edition of the Canon, see Avicenna, The Canon of Medicine (al-Qānūn fìl-tibb), adapted by Laleh Bakhtiar from translations by O. Cameron Gruner, and Mazar H. Shah, 5 vols (Chicago: Great Books of the Islamic World, 1999-2014).

9. Laleh Bakhtiar, Introduction to Avicenna, The Canon of Medicine, 1; see Fen [Part/Lecture] 1, Doctrina 6.

10. See Danielle Jacquart, 'Medieval Scholasticism', in Western Medical Thought from Antiquity to the Middle Ages, ed. by Grmek, 197-240, 214-16. For a comprehensive account of Avicenna's Canon with reference to Gerard of Cremona's translation, see Siraisi, Avicenna in Renaissance Italy, ch. 2, 'The Canon of Avicenna', 19-40; on the dissemination of the Canon in the medieval period, see Siraisi, ch. 3, "The Canon in the Medieval Universities', 43-76, in particular, 43-47.

11. See Jacquart, 'Medieval Scholasticism', 236, and Webb, The Medieval Heart, 21.

12. Constantine, Pantegni, Theorica IV.19, Lyons edition, 1515, cited in Charles Burnett, 'The Chapter on the Spirits in the Pantegni of Constantine the African', in Constantine the African and 'Ali Ibn al-'Abbas 
al-Mağùsī: The Pantegni and Related Texts, ed. by Charles Burnett and Danielle Jacquart, Studies in Ancient Medicine 10 (Leiden: E. J. Brill, 1994), 99-120: 105-06; Grudzen, Medical Theory About the Body and the Soul, 63-64; 200-01.

13. John Trevisa, On the Properties of Things, ed. by M. C. Seymour, 3 vols (Oxford: Oxford University Press, 1975), vol. 1, III.15, 104-05; for the Latin, see Bartholomaeus Anglicus, De rerum proprietatibus (1601; Frankfurt: Minerva, 1964). Subsequent references are from this edition cited by book, chapter, and page number.

14. See also Pedro Gil Sotres, 'The Regimens of Health', in Western Medical Thought from Antiquity to the Middle Ages, ed. by Grmek, 291-318.

15. Webb, The Medieval Heart, 52-53, and see 50ff for a discussion of the porous heart in poetic, theological and philosophical works.

16. See G. Verbeke, L'Evolution de la doctrine du 'pneuma' du stö̈cisme à $S$. Augustin, étude philosophique (Paris: Desclée, de Brouwer, 1945), 489508.

17. For a more extended discussion of Chaucer's romance writings, see my 'The Play of Breath: Chaucer's Narratives of Feeling', in Arthur Rose, Stefanie Heine, Naya Tsentourou, Corinne Saunders, and Peter Garratt, Reading Breath in Literature, Palgrave Studies in Literature, Science, and Medicine (New York: Palgrave Macmillan, 2019), 17-37.

18. Chaucer, Geoffrey, The Romannt of the Rose, in The Riverside Chancer, ed. by Larry D. Benson, 3rd edn (Oxford: Oxford University Press, 1988), Fragment B, 1865-68 (Fragment B is less securely attributed to Chaucer). Subsequent references to the works of Chaucer are from this edition, cited by line number.

19. Floris and Blanchefleur, in Of Love and Chivalry: An Anthology of Middle English Romance, ed. by Jennifer Fellows, Everyman's Library (London: Dent, 1993), 43-72, 1. 246. Subsequent references are from this edition, cited by line number.

20. King Horn, in Of Love and Chivalry, 1-41, 11. 251-52, 263. Subsequent references are from this edition, cited by line number.

21. Marie de France, Guildelïec and Guilliadun, or Eliduc, in The Lais of Marie de France: Text and Translation, ed. and trans. by Claire M. Waters, Broadview Editions (Peterborough, ON: Broadview Press, 2018), 300$59,11.853-58$. Subsequent references are from this edition, cited by line number.

22. The Story of Apollonius, King of Tyre, trans. by Gerald N. Sandy, in Collected Ancient Greek Novels, ed. by B. P. Reardon, 2nd edn (Berkeley: University of California Press, 2008), 736-72: 752. Subsequent references are from this edition, cited by page number.

23. John Gower, Confessio Amantis, The English Works of John Gower, ed. by G. C. Macaulay, 2 vols, Early English Text Society, ES 81 and 82 
(London: Oxford University Press, 1900, 1901), vol. 2, Book VIII, 11. 1056,1060 . Subsequent references are from this edition, cited by book and line number.

24. For a more extended discussion of breath in The Book of Margery Kempe with reference to Julian of Norwich's Revelations of Divine Love and other works, and to the connections between breath and prayer, see my article with Amy Appleford, 'Reading Women in the Medieval Information Age: The Life of Elizabeth of Spalbeek and The Book of Margery Kempe', Studies in the Age of Chancer 42 (2020), 253-81.

25. Richard Rolle, The Fire of Love, trans. by Clifton Wolters (Harmondsworth: Penguin, 1972), Prologue, 45; for the original, see The 'Incendium Amoris' of Richard Rolle of Hampole, ed. by Margaret Deanesly (Manchester: Manchester University Press, 1915), Prologue, 145.

26. Pearl, in The Poems of the Pearl Manuscript: 'Pearl', 'Cleanness', 'Patience', 'Sir Gawain and the Green Knight', ed. by Malcolm Andrew and Ronald Waldron, Exeter Medieval Texts and Studies, 5th edn (Exeter: Exeter University Press, 2007), 52-110, 1. 59, and see note. Subsequent references are from this edition, cited by line number.

27. Julian of Norwich, Revelations of Divine Love, ed. by Barry Windeatt (Oxford: Oxford University Press, 2016), The Long Text, ch. 2, 30. Subsequent references are from this edition, cited by chapter and page number. For a translation see Julian of Norwich, Revelations of Divine Love, trans. by Barry Windeatt, Oxford World's Classics (Oxford: Oxford University Press, 2015).

28. The Book of Margery Kempe, ed. by Barry Windeatt (Cambridge: D. S. Brewer, 2004), 11. 74, 1071-72. Subsequent references are from this edition, cited by line number. The unique manuscript, a copy written by a Norfolk scribe named 'Salthows', dates to $c a$. 1450. For a translation see The Book of Margery Kempe, trans. by B. A. Windeatt, Penguin Classics (London: Penguin Books, 1985, repr. 2004).

29. Kempe's behaviours have been retrospectively diagnosed as manifestations of hysteria, psychosis, and temporal lobe epilepsy. See further Richard Lawes, 'The Madness of Margery Kempe', in The Medieval Mystical Tradition: England, Ireland, and Wales. Exeter Symposium VI: Papers Read at Charney Manor, July 1999, ed. by Marion Glasscoe (Cambridge: D. S. Brewer, 1999), 147-67: Lawes argues for a diagnosis of temporal lobe epilepsy. On the limits of psychopathological diagnoses see Alison Torn, 'Madness and Mysticism: Can a Mediaeval Narrative Inform our Understanding of Psychosis?', History and Philosophy of Psychology 13 (2011): 1-14; and 'Looking Back: Medieval Mysticism or Psychosis', The Psychologist 24/10 (2011): 788-90. 


\section{Selected Bibliography}

Fanous, Samuel, and Vincent Gillespie, eds 2011. The Cambridge Companion to Medieval English Mysticism. Cambridge: Cambridge University Press.

Getz, Faye. 1998. Medicine in the English Middle Ages. Princeton: Princeton University Press.

Grmek, Mirko D., ed. 1998. Western Medical Thought from Antiquity to the Middle Ages. Co-ord. Bernardino Fantini. Trans. Antony Shugaar. Cambridge, MA: Harvard University Press.

Kemp, Simon. 1990. Medieval Psychology. New York: Greenwood Press.

Knuuttila, Simo. 2004. Emotions in Ancient and Medieval Philosophy. Oxford: Oxford University Press.

Kruger, Steven F. 1992. Dreaming in the Middle Ages. Cambridge: Cambridge University Press.

Orlemanski, Julie. 2019. Symptomatic Subjects: Bodies, Medicine, and Causation in the Literature of Late Medieval England. Philadelphia: University of Pennsylvania Press.

Rawcliffe, Carole. 1995. Medicine and Society in Later Medieval England. Stroud: Sutton.

Siraisi, Nancy G. 1990. Medieval and Early Renaissance Medicine: An Introduction to Knowledge and Practice. Chicago: Chicago University Press, 1990.

Webb, Heather. 2010. The Medieval Heart. New Haven, CT: Yale University Press.

Open Access This chapter is licensed under the terms of the Creative Commons Attribution 4.0 International License (http://creativecommons.org/licenses/ by $/ 4.0 /$ ), which permits use, sharing, adaptation, distribution and reproduction in any medium or format, as long as you give appropriate credit to the original author(s) and the source, provide a link to the Creative Commons license and indicate if changes were made.

The images or other third party material in this chapter are included in the chapter's Creative Commons license, unless indicated otherwise in a credit line to the material. If material is not included in the chapter's Creative Commons license and your intended use is not permitted by statutory regulation or exceeds the permitted use, you will need to obtain permission directly from the copyright holder.

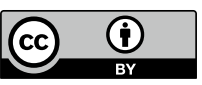

